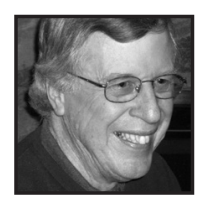

\title{
Michigan's Great Lakes Stewardship Initiative: A Statewide Place-Based Education Effort to Connect Schools to Communities
}

\author{
Gregory A. Smith, Lewis \& Clark College
}

\section{ABSTRACT}

The Great Lakes Stewardship Initiative (GLSI) has for 10 years been engaged in the systematic introduction of place-based learning approaches with an environmental and ecojustice focus throughout the state of Michigan. It has sought to create strong partnerships between schools and local organizations and agencies with the intent of cultivating knowledgeable and active citizen stewards. By the 2015-2016 academic year, the GLSI had worked with teachers in 283 schools, engaging over 80,000 students in its projects, demonstrating how place-based approaches can be brought to scale in both rural and urban communities.

wo upper elementary school boys stand behind a computer screen
with remote controls in hand. Below them is a slow moving river where
a remotely operated underwater vehicle (ROV) attached to a yellow cable floats just below the surface of the water. Equipped with a video camera, the ROV allows them to look for rusty crayfish, an invasive species that has become problematic in a northeast Michigan watershed close to the small town of Alpena. The boys' findings will help local fisheries scientists determine whether the crayfish population is increasing or decreasing.

In another section of the river, boys and girls in waders are collecting zebra mussels with long-handled nets. They bring these ashore and place them in white trays on tables where they measure their length and weigh them. Anjie Bowen, 
a state biologist with Michigan's Department of Natural Resources, explains that they will compare their current measurements with data from earlier years. Other students test the water for its $\mathrm{pH}$ level, temperature, and turbidity. Their teacher, Bob Thomson, stands back and watches his students at work. He says he has found that involving fifth graders in research projects like this one is the surest way to engage them in science learning. Thomson remarks, "They retain 70\% more than they would if they only learned it from a textbook." Partnering with biologists from the DNR also means he can rely on the expertise and support of people with finely honed research skills to make sure data collected by his students are both credible and useful. He notes, as well, that experiences that require taking averages and assessing assumptions based on data make classroom math lessons much more meaningful. He doesn't have to explain why it's important to learn this material.

Thomson's students are among the 80,000 children and youth who have participated in programs associated with the Great Lakes Stewardship Initiative (GLSI), ${ }^{1}$ an effort that since 2007 has been working to increase the environmental literacy and responsibility of Michigan's young citizens. Thanks to a 10-year $\$ 10.9$ million grant from the Great Lakes Fishery Trust, staff at nine regional GLSI hubs have provided professional development, helped support the formation of school-community partnerships, and expanded the use of local resources and learning opportunities in the 283 schools that were part of the GLSI network by the 2015-2016 academic year. A small central staff coordinates the GLSI and provides technical assistance to its hubs.

The Great Lakes Fishery Trust was created in 1996 to help compensate for damage done to the Lake Michigan fisheries stocks as a result of the operation of the Ludington Pumped Storage plant, a hydroelectric facility that pumps lake water into a reservoir at a higher elevation during hours when demand for electricity is low and then allows the water to flow back downhill, generating power when demand for electricity is high. This process, although tied to a renewable resource, nevertheless resulted in the deaths of over 181 million fish a year, leading to a lawsuit and settlement that required the plant to erect a fish barrier and establish a fishery trust (among other responses) for the duration of the plant's license which is scheduled to expire in 2019. The terms of the settlement required ratepayers to contribute to the Fishery Trust and its work, including educational activities aimed at better preparing Michigan residents to care for the Great Lakes, and the streams and rivers that empty into them. For nearly the past decade, the Great Lakes Stewardship Initiative has been the primary vehicle through which the Trust has sought to accomplish this goal. 


\section{Place-Based Education}

In its effort to respond to its educational mandate, the GLSI adopted an approach to teaching and learning called place-based education (or place- and communitybased education), believing that, coupled with a statewide infrastructure (the regional hubs), it would provide a more promising approach to stewardship education than a more prescriptive and generalized curriculum. Place-based education (PBE) encourages teachers to incorporate local knowledge, resources, and experiences into the curriculum and instruction children and youth encounter in school. It aims to diminish the boundaries that often separate classrooms from communitiesboundaries that can make it difficult for many children to understand the relationship between what they encounter in school and what goes on outside. More than a century ago, John Dewey (1959) wrote:

From the standpoint of the child, the great waste in the school comes from his [sic] inability to utilize the experiences he gets outside the school in any complete and free way within the school itself; while, on the other hand, he is unable to apply in daily life what he is learning at school. That is the isolation of the school, its isolation from life. (pp. 76-77)

Teachers who incorporate place-based educational approaches strive to overcome that isolation by bringing community members into the classroom or purposely involving them in children's work out in the community. They furthermore seek to engage students in projects that have value beyond the classroom and provide them with the opportunity to participate as citizens in efforts to enhance both the social and natural environments in which they live.

Ethan Lowenstein (2016), the director of the GLSI hub that serves Southeast Michigan, observed in a local community magazine that:

In our experience, $\mathrm{PBE}$ - using the local community, including the environment, as the primary site for eliciting curiosity, posing questions, and envisioning possibilities and then acting to bring them into the world-is the most promising approach to education given our historical moment. While the PBE approach can be considered good old "progressive education," aiming to meet the needs of the whole child, what makes it different is its central focus on healing relationships with each other and fellow community members in the natural world (the plants, animals, water), and in our particular place over long periods of time. (p. 84) 
David Greenwood (previously Gruenewald), Canada's Research Chair in Environmental Education at Lakehead University, wrote in 2003 that place-based education can assist that healing by engaging in what he called "reinhabitation" and "decolonization." Reinhabitation involves giving students opportunities to participate in activities aimed at restoring or protecting the health of local natural and social environments. Decolonization requires identifying factors or practices that diminish that health, including forms of discrimination that result in environmental injustice. What is striking about the efforts of the Great Lakes Stewardship Initiative is that its participating educators are discussing and, in some locales, beginning to act on both of these dimensions of place-based education. Especially in Rust Belt communities like Detroit and Flint that have borne the full brunt of deindustrialization and white flight, acknowledging the political as well as the technological and social nature of contemporary ecological challenges has been essential.

The intentional dissemination of place-based educational approaches is something that began in the mid-1990s with the advent of the Annenberg Rural Challenge, a \$50 million five-year project that supported reform initiatives in 26 districts, regions, or states across the U.S. aimed at encouraging educators to begin imagining and enacting learning experiences that would allow students to contribute to community development and environmental stewardship. At roughly the same time, David Sobel (2004), a teacher educator at Antioch University New England, received funding to start the Community-based School Environmental Education (Co-SEED) program. Lasting more than a decade, Co-SEED spurred place-based educational efforts in both urban and rural schools in Massachusetts, Vermont, New Hampshire, and Maine. Many of the participating schools continue to implement place-based approaches. Gerald Lieberman at the State Education and Environment Roundtable in California has also been associated with the implementation of a wide range of place-based educational experiments in the U.S.; Lieberman called his approach using the Environment as an Integrating Context (Lieberman \& Hoody, 1998). In referring to the environment, Lieberman included not only the natural world, but also its cultural, political, historical, and economic dimensions. Other educators and schools in the U.S. and elsewhere were also adopting these approaches as they became familiar with them or simply because of their own predisposition to move teaching and learning beyond classroom walls. To some extent, the term place-based education has served to bring like-minded teachers already engaged in this work together, allowing for the formation of study groups and coalitions to overcome the isolation such innovators often experience. 


\section{Rooting Place-Based Education in Michigan}

What is important about the work of the Great Lakes Stewardship Initiative is its statewide focus and the fact that it had access to significant resources over a long enough time to make the implementation of place-based learning more than a teacherby-teacher or school-by-school endeavor. The adoption of an organizational structure based upon regional hubs furthermore allowed people in different parts of Michigan to create programs that met their own unique conditions and needs while at the same time advancing a common agenda. This predisposition to be flexible has meant that a variety of different entities have joined in the work of the GLSI. Fiscal agents for the nine hubs (see Figure 1) include institutions of higher learning, a conservation district, a community foundation, a watershed partnership, an intermediate school district, and a regional center for science, math, and environmental education. This level of diversity has allowed people with a range of perspectives to participate in rolling out GLSI programs, an important factor in an effort that sought to bridge the gap that so often exists between schools and their communities.

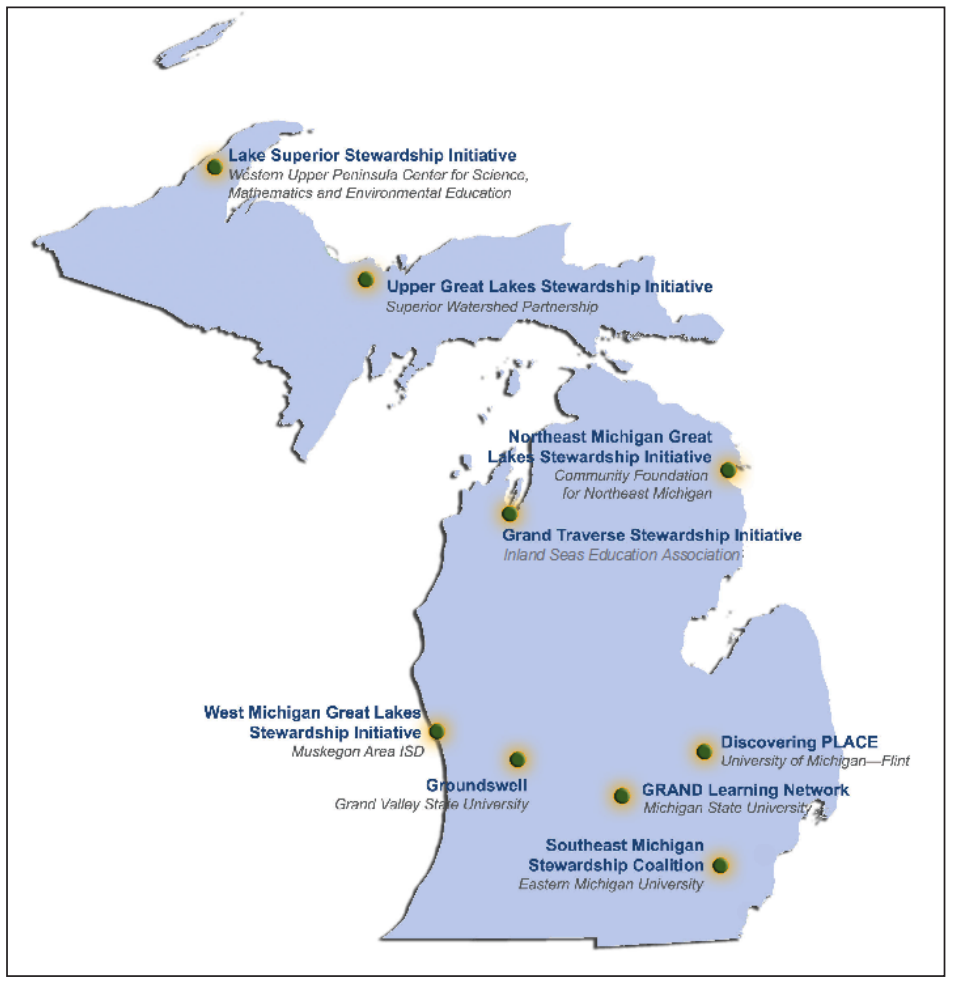

Fig. 1: Great Lakes Stewardship Initiative (used with permission) 
The central GLSI staff initially sought out likely partners in Michigan's nine diverse regions, reviewed proposals, distributed grants to the hubs, and offered much of the initial professional development regarding place-based education. Central to this process was the requirement that these organizations solicit the support of a wide range of stakeholders as they developed their plans and identified important local stewardship needs and issues. In the years since, the GLSI staff have organized an annual conference, pursued additional private and governmental funding at the national level, and worked to encourage state policy changes aimed at making PBE easier to implement during a period when political and corporate leaders have focused more on raising test scores than developing well-informed and active citizen stewards. The GLSI also exercises oversight and evaluation responsibilities regarding activities in the different hubs, sharing its vision and encouraging its regional organizations to find alternative sources of funding to assure their continuity when resources are no longer available from the Great Lakes Fishery Trust.

The hubs can be found in every part of Michigan from the Upper Peninsula to Detroit. They demonstrate varying levels of activity, but each is responsible for recruiting new schools and teachers into this work, providing professional development, organizing their own regional meetings and conferences, identifying agency and community partners, distributing their own small grants, and assisting their participants in local fund-raising activities. At the Southeast Michigan Stewardship Coalition (SEMIS), staff engage in coaching, mentoring, coalition building, whole-school professional development, collaborative assessment, and place-based curriculum co-development. The organization provides micro-grants up to $\$ 1500$ for teachers just beginning to experiment with place-based education, teacher leadership grants for action research projects implemented by veteran teachers, and affinity group grants to assist teams of teachers to meet informally with one another for meals, create book groups, or attend conferences. Hub staff across the state also act as the public face for GLSI efforts as they are interviewed by the press or write articles for local distribution to publicize the work that is taking place in schools associated with the initiative.

Over and beyond this kind of organizational and financial support, one of the most important roles of the hubs has been to provide a means by which individual teachers or teams of teachers in schools throughout a region are able to interact with one another, gain affirmation, and move from the margins of school decision-making to the center. Skilled hub leaders can also knit together coalitions of schools, agencies, businesses, and community-based organizations able to advance this work by acquainting other local leaders with the benefits that place-based educational approaches can bring to students, schools, and communities. The result has been 
the development of partnerships that are providing young people with otherwise out-of-reach learning experiences, and their communities with the energy, creativity, and participation of youth in efforts to address important community needs. A sample of partners from the Southeast Michigan Stewardship Coalition and the Northeast Michigan Great Lakes Stewardship Initiative includes:

Huron River Watershed Council

National Oceanic and Atmospheric Agency

Great Lakes Environmental Research Lab

Michigan Department of Natural Resources

Urban Forest Stewardship Project

Greening of Detroit

Cass Community Social Services

Thunder Bay National Marine Sanctuary

U.S. Fish and Wildlife Service
Leslie Science and Nature Center

Michigan Sea Grant

Clinton Watershed Council

EcoWorks

Friends of the Rouge Park

Matrix Theatre Company

SW Detroit Environmental Vision

Huron Pines

Besser Museum for NE Michigan

One of the guiding principles informing the work of the Great Lakes Stewardship Initiative has been that people in each of the states' nine hubs should be allowed to uncover and develop the assets encountered in their own regions and then engage students in appropriate forms of problem solving and action to address needs that they or their community partners have identified. At the same time, hubs are to fulfill the organization's overriding goals to

- Help young people become effective and motivated environmental stewards

- Encourage schools and community organizations to work together for mutual benefit

- Create a sustained effort across Michigan to expand classrooms and strengthen communities

- Serve as a beacon for the betterment of education, communities, and the environment (GLSI, 2016)

The result has been a wide range of varying responses and projects that build upon the possibilities, resources, talents, and interests of educators and partners in communities throughout the state.

This model of school change is especially appropriate for place-based education. Instead of blindly prescribing a single set of guidelines and curricula to be implemented with fidelity in every school and community regardless of their unique characteristics, the GLSI has allowed different people in different places to realize a shared vision in 
their own ways. Activities have ranged from beach clean-ups and abandoned-tire collection to restoration projects, the creation of vegetable or native plant gardens to raising and then releasing salmon or trout, trail building and maintenance to habitat monitoring and local science investigations, the weatherization of neighborhood homes to school energy audits, investigations of local history and archeology to the development of locally relevant electives or required courses. On some occasions, students' work leads them to become involved with local decision-making bodies and policymakers. On others, courses or after-school clubs acquaint young people with organizations and activists in their community working to enhance the environmental and social health of their region. The next section will describe in more detail the way GLSI efforts are being enacted in two settings, one urban and the other rural.

\section{GLSI Place-Based Educational Projects on the Ground}

\section{Detroit Institute of Technology at Cody}

Students at the Detroit Institute for Technology at Cody (DIT) have been addressing a collection of environmental and social justice issues and needs since 2010 when teachers there began their affiliation with the Southeast Michigan Stewardship Coalition (SEMIS), the GLSI hub for this region of the state. DIT, one of three small high schools clustered together in the Frank Cody High School in a western suburb of Detroit, enrolls approximately 450 students, 95\% of whom are African American, and $69.1 \%$ qualify for free or reduced lunch. Educators at DIT have incorporated projects aimed at engaging students in activities that address the school's focus on science, technology, engineering, the arts, and mathematics (STEAM). They have done this primarily by collaborating with a longstanding Detroit nonprofit called EcoWorks, as well as participating in the Detroit Public Schools Go Green Challenge (DPSGGC).

The Detroit Institute of Technology's collaboration with EcoWorks has brought students into the community in an especially direct way. In existence for 30 years, EcoWorks provides "services at the intersection of community development, sustainability, and social justice" (EcoWorks Detroit, 2016). One of EcoWorks' projects is known as the Youth Energy Squad (YES). Since 2011, YES has been working with numerous schools throughout the Detroit region supporting environmentally focused activities as well as youth development opportunities. At the DIT, YES staff trains students to become home energy consultants and has provided them with the skills 
and materials needed to weatherize over 1,000 homes. EcoWorks estimates that homeowners throughout the city who have participated in their projects have realized energy savings of over $\$ 3$ million (Youth Energy Squad, 2016).

Students at the DIT have also been participating in the Detroit Public Schools Go Green Challenge. The aim of this district-wide project is to encourage hands-on learning experiences meaningful enough to lead "the next generation to practice sustainability in their homes and communities and become leaders in the green economy" (DPSGGC, 2016). To accomplish this, teachers are invited to make use of school facilities to create innovative lessons about recycling, energy conservation, water conservation, gardening, and nutrition with the potential of positively affecting student achievement and community welfare while reducing operating expenses. The DIT Green Team has addressed this challenge by creating a community garden, establishing a more comprehensive recycling program, and monitoring efforts to reduce energy and water use. In preparation for the creation of the garden, students honed a variety of academic skills as they interviewed community members about their thoughts regarding this project, surveyed the school site, took measurements based on their garden design, and developed plans for a potential greenhouse.

Chad Segrist, a teacher deeply involved with these efforts, emphasized the role that inquiry has played throughout the process of establishing the garden.

We initially met on a monthly basis, using inquiry-based questions to lead our discussion. What effect will it have? Who will be affected both positively and negatively? What would this mean to members of the community? Things like that. The inquiry led to new questions from students. We would have sit-downs where students would develop new questions, and with collaboration of other stakeholders we developed inquiry based "driving" questions that led [to] our next steps. (Southeast Michigan Stewardship Coalition, 2016)

These conversations parallel DIT teachers' use of Earth Force: A Curriculum for Community Action and Problem Solving. This curriculum lays out a systematic process for engaging students in the work of community organizers. It directs teachers' and students' attention to the value of conducting a community inventory as a means for selecting issues worthy of inquiry and action. It then provides guidance about how to investigate relevant policies and practices and identify changes they want to see. It walks them through the process of selecting a project goal and then developing an action plan. After engaging in the action, it points out the value of reflecting upon what they've done and learning from their successes, challenges, and failures. 
When Segrist first came to the school in 2012, he took the additional step of creating an after-school program called Cody Youth Ambassadors. In the 2015-2016 school year, a dozen students participated in this organization and took the lead in encouraging peer education and sharing student ideas about potential projects. Over and beyond the opportunity to make presentations to other students, educators, and the broader public, the Youth Ambassadors program has brought to the school the chance for students to join with other youth who are committed to making a difference in their community and gaining the skills that will allow them to do this with greater effectiveness as they get older. A ninth-grade boy who became a Youth Ambassador (YA) during his first year at the DIT said he was drawn to the organization because he had a "spark in his mind" about being a community change agent. He realized that if he became a YA he would find people who would help him overcome his sense of loneliness by listening to him (Lowenstein et al., 2016). For adults at the school who regularly associate with Youth Ambassadors, interactions with young people who are gaining their own voices have made it impossible to ignore the consequences of poverty and power imbalances; this has led them to craft place-based education initiatives that speak more authentically to the conditions that affect students' lives. This, as much as anything, is leading DIT teachers and their agency and university partners to acknowledge and then address the forms of oppression and discrimination that play such a significant role here in the suburban outskirts of Detroit.

\section{The Alpena School District}

The small town of Alpena, in northeast Michigan, has been the site of a wide variety of place-based educational activities since the formation of the Great Lakes Stewardship Initiative. The opening paragraphs of this article describe a project undertaken by students at the district's Ella White Elementary School. Colleagues in other elementary schools as well as at the Thunder Bay Middle School and the Alpena High School are similarly reaching into the community to provide meaningful learning experiences for students. Alpena has a population of a little over 10,000 people. The town is small by conventional standards, but it and Traverse City, on the west side of the mitten that Michigan's lower peninsula resembles, are the two largest municipalities in this part of the state. In contrast to Detroit, Caucasians make up nearly $97 \%$ of the population in the city, itself, and $94 \%$ in the school district. As in many rural communities, however, poverty is common, with $56.3 \%$ of Alpena's students categorized as economically disadvantaged, more than twice the national average. Lumber and shipping were once major industries, but both have become less significant. A limestone quarry, a cement processing plant, a factory that manufactures concrete blocks, and tourism provide the primary sources of income for the area's residents. 
At the Ella White Elementary School, fifth-grade teacher Bob Thomson was already experimenting with place-based educational experiences before the creation of the Great Lakes Stewardship Initiative. After once reading a novel with his students that described creating a shelter in the wilderness, he took his students outside to create their own shelters. He later met a community member who introduced him to the underwater robots his students now use to study rusty crayfish. What the GLSI has brought to him is access to like-minded educators around the state and his own region, professional development experiences for colleagues interested in adopting place-based educational practices, and access to a broader range of partners and funders for the projects he and his students want to implement. His introduction to underwater robots brought with it the possibility of his students' work contributing to the efforts of various state and national agencies to help control invasive species and enhance the populations of native species threatened by these newcomers to the Great Lakes. In addition to collecting data about population dynamics of non-native species, students also engage in activities designed to alert classmates and adults in the community about their impact and ways to reduce this. Fishermen, for example, have used the hard-shelled rusty crayfish as bait far outside their native range in the Ohio River basin. When unused, crayfish are dumped into bodies of water outside their native habitat where they quickly overcome soft-shelled crayfish and disrupt the food chain. Students created posters and flyers and distributed them to the public about this situation. They made presentations to their classmates and community boards, requesting that they deal with these issues. They have also gotten involved in the policy arena in an effort to encourage the state to increase the allowable catch size of small-mouth bass, a predator that feeds on rusty crayfish (Grulke, 2013).

With regard to the restoration of native species, students raise lake trout in classroom aquariums and then release fingerlings near an artificial reef in Thunder Bay. Their hope is that when the fish mature, they will return to this area to spawn. Thomson has also brought a small sturgeon into the classroom to give students a chance to observe this prehistoric-looking creature up close. Sturgeons play an important role in the lake's ecology, and Thomson intends to see what he and his students can do to improve the fish's public image and the conditions that affect its health. With the help of a Michigan Sea Grant, students created, printed, and distributed a colorful poster featuring a masked and caped Super Sturgeon (aka Acipenser fulvescens). The poster describes the characteristics of this "native hero species" with its spiked armor and invisibility cloak, the fact that it is the longest living fish species in the Great Lakes, and the battles it faces to survive polluted water and hydroelectric plants. 
Thomson acknowledges that his early years as a place-based educator were taxing in terms of finding partners and gaining the funding needed to embark on some of these initiatives. By this point, however, agencies and resource professionals from outside the school are coming to him with ideas and possible projects, and the students themselves have become involved with grant writing. The benefits are abundantly clear, from the way students are educating the public to the role they can play in slowing the spread of invasive species. And for students, as fifth-grader Trevor Marwede observed, "I like learning about this stuff. It's fun to go outside and look for rusty crayfish and test the water" (in Grulke, 2013).

Science teachers Cheryl Mack and Tim Pollard at Thunder Bay Junior High School provide students in grades 6-8 with place-based learning experiences similar to those encountered in Bob Thomson's classes. A pivotal project between 2012-2015 has been participation in the Great Lakes Adopt-a-Beach program. During this time, students have engaged in shoreline habitat and water monitoring as well as clean-up activities at five Lake Huron beaches along a one-and-a-half-mile stretch of U.S. 23. Monitoring activities include the completion of a beach health assessment form as well the tracing of an invasive reed in northeast Michigan coastal wetlands. In addition to their clean-up work, students monitor the kinds and amounts of litter they find.

Shocked by the quantity of cigarette butts they were picking up, students decided to share their findings with the Alpena City Council in the hope that their elected representatives would be able to do something about what these young people saw as both an eyesore and a threat to the health of local ecosystems. A small team developed a presentation, met with the council, and was delighted when their suggestions were well received. The city council agreed to place more trash cans at the beaches under their jurisdiction. The mayor of Alpena also visited the class, commending students for their service to the community and their willingness to share their findings and concerns with decision makers.

At Alpena High School, a course entitled "Shipwreck Alley: Shipwreck Science and the Marine Sanctuary" makes the link between community service and academic learning even more explicit. When science teacher John Caplis was asked to serve on the steering committee of the nearby Thunder Bay National Marine Sanctuary, he pitched the idea of creating a class that would give students the chance to work side-by-side with marine archeologists, historians, and biologists. He figured that such a class would give students a chance to learn about the unique history of their region and the nearly 200 vessels that had sunk in nearby waters because of geological and meteorological hazards like reefs and fog. More than 80,000 people visit the 
sanctuary each year, and Caplis wanted to increase students' appreciation of their out-of-the way community as well as acquaint them with career possibilities they may have never before considered. He also saw the course as a powerful way to teach geology, physics, math, and history by engaging students in work that was tangibly beneficial to their community. After his fellow committee members and agency staff gave him the go-ahead, he wrote a curriculum, ran it by professionals at the Sanctuary, and with their approval started an elective class that has been sought after by a steady stream of students.

The class requires its participants to master information about the types of vessels used for commercial shipping in the Great Lakes, hazards they are likely to encounter, ways these dangers can be reduced, and the relevance of basic concepts of force and motion to marine safety. Students are also required to do mathematics exercises like the following:

Your assignment is to design an anchor system for a can buoy to mark the left side of a narrow channel in Thunder Bay. The buoy will be a cylinder with a height of 3 meters and a diameter of 1 meter. The buoy will be constructed of steel plate having a thickness of $6 \mathrm{~mm}$. The weight of the anchor system should be twice the buoyancy of the buoy if the buoy were completely submerged (as in a severe storm). The anchor system will include a weight and anchor chain. The buoy will be deployed in an area where the bottom depth is 20 meters. How heavy should the bottom weight be to meet these requirements? (National Oceanic and Atmospheric Agency Ocean Service Education, no date)

What makes this kind of challenge appealing for students is the opportunity to take part in a wide range of outside-of-classroom learning experiences where the reason for acquiring this level of mathematical and scientific skill is obvious.

Students, for example, make trips to the Great Lakes Maritime Heritage Centerpart of the Marine Sanctuary-where they have the opportunity to learn about ROV technology and how it can assist in underwater exploration. They are able to manipulate the robots in a pool where they negotiate a simulated wreck, take photos, and then construct a mosaic of the images they have collected. On the same day, they spend time in other labs where they have the opportunity to deepen their knowledge of environmental issues and conservation practices. Scientists and technicians associated with the Marine Sanctuary play a major role during these field trips, demonstrating what it means to be a practicing scientist. Students also spend another day in the city pool learning how to snorkel and scuba dive, additional skills that are part of the work life of people at this facility. 
A project more related to the humanities than the sciences-another important element of the Shipwreck Alley class - takes students into the community to interview local fishermen and collect their stories about what it was like to work and live on Lake Huron. The oral histories they gather will be contributed to the creation of an interpretive exhibit at the Besser Museum in Alpena, linked to the restoration of the Katherine $\mathrm{V}-\mathrm{a}$ historic commercial fishing boat. Students' writing and media skills are also being used to create presentations during expeditions on a glass-bottom boat that makes it possible for tourists to see some of the submerged vessels. Students write that,

We want to help passengers understand what they are seeing through the glass bottom windows. Seeing a shipwreck for the first time is cool, but learning what it did, how it sank, and why it is still important today . . . that makes the journey worthwhile. (Shipwreck Alley, 2016).

Judging by the news and TV articles available on-line about the Shipwreck Alley course, it has gained public attention. It has also had a valuable impact on students who have had the chance to participate in this place-based education project. One student observed,

Because of this class, I became a volunteer at the Sanctuary. Then through that, I submitted an application to a program called Ocean for Life, which is a NOAA program [that] took place in California. So I got accepted to that and I went there this summer. . I'm really interested in having a career path in marine archeology or maritime biology... It all started from this class, so that's really cool. (in Rote, Schroeder, \& d'Augustino, 2015, p. 23)

Teacher John Calpis also observed that prior to taking this class, few students believed it would be possible for them to find jobs in their home town that interested them. Interacting with scientists at the Marine Sanctuary showed them that they were wrong and that there are ways they can remain in Alpena and use their talents to strengthen and grow their community.

Students in Alpena, Michigan are offered a variety of opportunities to learn in and outside of the classroom about the unique characteristics of their own place on the planet. They are also encountering numerous opportunities to become involved in projects that allow them to contribute their energies to their community and region, affirm their own value, and deepen their connection to the people and places that surround them. 


\section{Student and Teacher Perspectives About the Great Lakes Stewardship Initiative}

A formal evaluation of the work of the GLSI across all hubs is still in progress, but an evaluation of the Northeast Michigan Great Lakes Stewardship Initiative was published in December 2015. In this report, researchers identified a number of aspects of place-based approaches that students and teachers believed are especially valuable. For students, these included the fact that they were often fun, focused on future and potential careers, incorporated hands-on learning, and were connected to the community. The responses of 197 students to the following questions are especially revealing. Scores range from $1=$ strongly disagree, to $5=$ strongly agree.

\section{Table 1}

\section{Evaluation of the Northeast Michigan Great Lakes Stewardship Initiative}

MEAN SCORE

1. What $I$ do and learn in this [PBE Class or Project] is meaningful and relevant to my life.

2. In school, I often wonder, "When will I ever need to know this?"

3. I often wonder the same question in this [PBE Class or Project]?

4. I feel more engaged in this [PBE Class or Project] than I do in my 3.8 other classes.

5. I am more motivated to do well in this science class than in my other classes.

6. I am more involved in my community because of this science class.

7. I want to be more involved in my community because of this 3.6 science class.

8. Overall, I feel connected to my community.

3.8

3.6

2.7

3.5

3.2

(from Rote, Schroeder, \& d'Augustino, 2015, p. 10)

Clearly, students are encountering experiences in classes using place-based approaches that have gained their interest and allegiance in ways that stimulate both academic engagement and an interest in civic participation. 
Findings from a study published in 2016 regarding the impact of place-based learning experiences on 240 students at Alpena Middle School reiterated these themes (Gallay, Marcklin-Polk, Schroeder, \& Flanagan, 2016). Opportunities to learn about and act on important local phenomena increased students' environmental sensitivity, environmental behaviors, community attachment, and civic competencies. Students' responses to open-ended questions demonstrated the pride they take in participating in environmental clean-up and restoration projects, and the value they place on applying their emerging knowledge to community concerns.

Interviews with teachers surfaced similar but slightly different issues. From teachers' perspective, this kind of teaching and learning was resulting in improved teamwork, more responsibility and life skills as well as student ownership, purposeful and meaningful lessons, enhanced motivation, and a deeper regard for their own community. According to a high school teacher, "Students seem to be more engaged when [they are] doing exciting, interesting things in the class.... Everybody's firing on all cylinders" (in Rote et al., 2015, p. 8).

The Great Lakes Stewardship Initiative has for nearly a decade been involved in the creation of learning opportunities that are drawing students into lived and academic experiences that are deepening their knowledge and ties to their own places and communities in ways that appear to be achieving the organization's mandate to nurture citizen stewards. Organizationally, it offers a model that could be adopted in other states or provinces as a means for disseminating place-based educational approaches. From the standpoint of the billions of dollars that have been invested in the mixed results associated with the standards and accountability movement over the past two decades, the $\$ 10.9$ million spent in Michigan to create meaningful lessons, units, and projects for students that benefit both them and their communities seem affordable and worthwhile. Educators and policymakers interested in reclaiming the democratic purposes of education, enhancing the local environment, developing citizen stewards, and adopting engaging forms of instruction that lead students to start "firing on all cylinders" could learn much from what is happening there. 


\section{Note}

1. While researching this article I made extensive use of the websites associated with the Great Lakes Stewardship Initiative (http://www.glstewardship.org/), the Southeast Michigan Stewardship Coalition (http://semiscoalition.org/), and the Northeast Michigan Great Lakes Stewardship Initiative (http://www.nemiglsi.org/). Factual and descriptive information, resources, and case studies encountered at these sites provide a multi-dimensional perspective about what the GLSI is doing and accomplishing in Michigan. I also drew upon scenes from Bob Giner's film about the GLSI entitled Growing Up Green (available at www.docmakeronline.com).

\section{References}

Detroit Public Schools Go Green Challenge. (2016). Retrieved from https://dpsgogreen. wordpress.com.

Dewey, J. (1959). School and society. New York: Teachers College Press.

EcoWorks Detroit. (2016). Retrieved from http://www.ecoworksdetroit.org/.

Gallay, E., Marcklin-Polk, L., Schroeder, B., \& Flanagan, C. (2016). Place-based stewardship education: Nurturing aspirations to protect the rural commons. Peabody Journal of Education, 91(2), 155-175.

Great Lakes Stewardship Initiative. (2016). Retrieved from http://www.glstewardship. org.

Gruenewald, D. (2003). The best of both worlds: A critical pedagogy of place. Educational Researcher, 32(4) (May), 3-12.

Grulke, N. (2013). Researching rusty crayfish, Alpena News (October 12). Retrieved from http://www.nemiglsi.org/media/partners/ media/rusty_crayfish_alpena_news_2013. pdf)

Lieberman, G., \& Hoody, L. (1998). Closing the achievement gap: Using the environment as an integrating context for learning. Poway, CA: State Education and Environment Roundtable.

Lowenstein, E. (2016). Green living: Growing visionary education communities. The Crazy Wisdom Community Journal: Southern Michigan's Conscious Living Magazine, 62(Winter), 84.
Lowenstein, E., Voelker, L., Sylvester, J., Roundtree, A., Harris, K., Segrist, C., et al. (2016). Fostering youth leadership in urban place-based education," Green Teacher, 110. Retrieved from http://greenteacher.com/ fostering-youth-leadership-in-urban-places/

National Oceanic and Atmospheric Agency Ocean Service Education. (no date). Shipwreck Alley: Thunder Bay National Marine Sanctuary/Grades 9-12, Geography, Physical Science, Math. Retrieved from http://oceanservice.noaa.gov/education/ lessons/shipwreck_alley.html.

Rote, Z., Schroder, B., \& d'Augustino, T. (2015). Place-based education: Engagement from the student perspective. Retrieved from http://www.miseagrant.umich.edu/wpcontent/blogs.dir/1/files/2012/05/15-206Place-Based-Education-Report.pdf.

Shipwreck Alley. (2016). Retrieved from https://shipwreckalley.wordpress.com/.

Sobel, D. (2004). Place-based education: Connecting classrooms \& communities. Great Barrington, MA: The Orion Society.

Southeast Michigan Stewardship Coalition. (2016). Retrieved from http://semiscoalition. org/shared-stories/shared story-ditc/.

Youth Energy Squad. (2016). Retrieved from www.youthenergysquad.org/\#itake-action/ vxuej. 


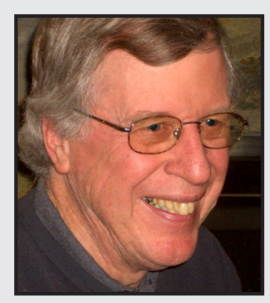

Gregory A. Smith is a recently retired education professor from Lewis \& Clark College in Portland, Oregon. He earned his $\mathrm{PhD}$ in educational policy studies from the University of Wisconsin-Madison in 1989 and is the author, co-author, editor, or co-editor of six books that address the relationship between schools, communities, and the environment. The most recent volumes include Place-Based Education in the Global Age: Local Diversity (with David Greenwood) and Place- and Community-Based Education in Schools (with David Sobel). He has spoken about place-based education across the United States as well as in Canada, Germany, the United Kingdom, Japan, New Zealand, and Australia. 